\title{
Pengaruh Profitabilitas, Capital Intensity, dan Inventory Intensity pada Penghindaran Pajak
}

\author{
Ida Ayu Intan Dwiyanti ${ }^{1}$ \\ I Ketut $\mathbf{J a t i}^{2}$ \\ ${ }^{1,2}$ Fakultas Ekonomi dan Bisnis Universitas Udayana (Unud), Bali, Indonesia \\ e-mail: dayuintan97@gmail.com
}

\begin{abstract}
ABSTRAK
Penelitian ini bertujuan untuk mengetahui pengaruh profitabilitas, capital intensity, dan inventory intensity pada penghindaran pajak. Penelitian ini dilakukan pada perusahaan manufaktur yang terdaftar di Bursa Efek Indonesia periode 2015-2017 dengan populasi sebanyak 150 perusahaan. Penentuan sampel pada penelitian ini adalah dengan metode non probabilaty sampling dan dengan teknik purposive sampling, sehingga diperoleh sampel penelitian sebanyak 63 perusahaan. Teknik analisis data yang digunakan dalam penelitian ini adalah analisis regresi linear berganda. Berdasarkan hasil analisis regresi linear berganda yang menunjukkan bahwa seluruh variabel bebas pada penelitian ini, yaitu profitabilitas, capital intensity, dan inventory intensity berpengaruh positif pada penghindaran pajak.
\end{abstract}

Kata kunci: Profitabilitas, capital intensity, inventory intensity, penghindaran pajak

\begin{abstract}
This study aims to determine the effect of profitability, capital intensity, and inventory intensity on tax avoidance. This research was conducted at manufacturing companies listed on the Indonesia Stock Exchange for the period 2015-2017 with a population of 150 companies. Determination of the sample in this research is by non probabilaty sampling method and by purposive sampling technique, so that the research sample is 63 companies. The data analysis technique used in this study is multiple linear regression analysis. Based on the results of multiple linear regression analysis which shows that all independent variables in this study, namely profitability, capital intensity, and inventory intensity have a positive effect on tax avoidance.
\end{abstract}

Keywords: Profitability, capital intensity, inventory intensity, tax avoidance

\section{PENDAHULUAN}

Penghindaran pajak (tax avoidance) merupakan manipulasi penghasilan secara legal yang masih sesuai dengan ketentuan peraturan perundang-undangan perpajakan untuk mengefisiensikan pembayaran jumlah pajak yang terutang (Zain, 2007). Penghindaran pajak saat ini menjadi perhatian utama hampir seluruh negara. Penghindaran pajak menurut Hanlon dan Heitzman (2010) yaitu upaya untuk mengurangi besarnya nilai pajak eksplisit melalui upaya perencanaan pajak 
Ida Ayu Intan Dwiyanti dan I ketut Jati. Pengaruh ...

dalam rentang legal dan ilegal. Xynas (2010) mengatakan tindakan penghindaran pajak dilakukan secara legal (lawful) dengan memanfaatkan celah (loopholes) yang terdapat dalam peraturan perpajakan yang ada untuk menghindari pembayaran pajak yang jumlahnya lebih besar.

Praktik penghindaran pajak umumnya dilakukan dengan memanfaatkan adanya perbedaan regulasi perpajakan yang dirancang sedemikian rupa agar tidak melanggar ketentuan pajak secara resmi, namun melanggar substansi ekonomi dari suatu kegiatan bisnis (Anissa, 2015). Penghindaran pajak merupakan persoalan yang rumit karena di satu sisi diijinkan, tetapi tidak diinginkan oleh pemerintah, sehingga muncul perbedaan kepentingan antara perusahaan dengan pemerintah dimana perusahaan selalu berusaha untuk menekan beban pajaknya serendah mungkin, sedangkan pemerintah selalu berusaha untuk meningkatkan penerimaan pajak Negara semaksimal mungkin setiap periode yang telah ditargetkan sesuai Anggaran Pendapatan Belanja Negara (APBN) (Ampriyanti dan Merkusiwati, 2016).

Upaya penghindaran pajak dapat dilihat dari terbitnya Surat Ketetapan Pajak Kurang Bayar (SKPKB). SKPKB merupakan salah satu produk yang dihasilkan dari pemeriksaan pajak. (Suandy, 2011:101) menjelaskan bahwa pemeriksaan pajak adalah kegiatan mencari, mengumpulkan, mengolah data dan keterangan lain dengan tujuan menguji kepatuhan pemenuhan kewajiban pajak dan untuk tujuan lain. SKPKB adalah surat ketetapan pajak yang menentukan tambahan atas jumlah kurang pajak yang telah ditetapkan (Resmi, 2012:34). 
Berikut ini merupakan tabel yang menunjukkan jumlah perusahaan manufaktur yang menerima SKPKB tahun 2015-2017.

Tabel 1.

Perusahaan Manufaktur yang terdaftar di Bursa Efek Indonesia yang menerima SKPKB Tahun 2015-2017

\begin{tabular}{ccc}
\hline Tahun & Jumlah Perusahaan & Jumlah Kurang Bayar (Rp) \\
\hline 2015 & 6 & $33,738,631,853$ \\
2016 & 18 & $2,282,989,913,699$ \\
2017 & 19 & $5,397,005,646,672$ \\
\hline Sumber: Data diolah, 2018 &
\end{tabular}

Tabel 1 menunjukkan perusahaan-perusahaan manufaktur yang menerima SKPKB tahun 2015-2017. Terdapat 6 perusahaan manufaktur yang menerima SKPKB pada tahun 2015 dengan total nilai sebesar Rp33,738,631,853. Pada tahun 2016 terjadi peningkatan jumlah perusahaan manufaktur penerima SKPKB menjadi sebanyak 18 perusahaan dengan jumlah total Rp2,282,989,913,699. Sedangkan pada tahun 2017 jumlah perusahaan manufaktur yang menerima SKPKB sebanyak 19 perusahaan dengan nilai sebesar Rp5,397,005,646,672. Perusahaan manufaktur yang menerima SKPKB terus meningkat dari tahun ke tahun dengan total nilai yang juga mengalami peningkatan. Hal ini berarti semakin banyak perusahaan yang tidak jujur dan tidak benar dalam melaporkan pajaknya. SKPKB diterbitkan apabila Direktorat Jendral Pajak (DJP) menemukan bahwa pajak terutang yang kurang dibayarkan oleh Wajib Pajak. Terbitnya SKPKB dapat mengindikasikan bahwa perusahaan tersebut melakukan tindakan penghindaran pajak, dimana perusahaan tersebut berusaha menghindari kewajibannya dengan mengurangi jumlah pembayaran pajak yang seharusnya dibayarkan. 
Ida Ayu Intan Dwiyanti dan I ketut Jati. Pengaruh ...

Sekjen Forum Indonesia Untuk Transparansi Anggaran (FITRA), Yenny Sucipto, mengakui bahwa pengelakan pajak merupakan masalah serius di Indonesia. Diduga setiap tahun ada Rp110 triliun yang merupakan angka penghidaran pajak. Kebanyakan adalah badan usaha, sekitar 80 persen, sisanya adalah wajib pajak perorangan (suara.com).

Industri manufaktur Indonesia juga tidak terlepas dari isu penghindaran pajak (tax avoidance). Seperti kasus yang terjadi pada PT Toyota Motor Manufacturing Indonesia (TMMIN). Direktorat Jenderal Pajak menganggap bahwa PT Toyota Motor Manufacturing Indonesia melakukan transfer pricing untuk melakukan penghindaran pajak. Transfer pricing adalah kebijakan penentuan harga untuk penjualan barang dan jasa yang terjadi dalam internal satu perusahaan atau satu kelompok perusahaan. Modus yang dilakukan oleh PT Toyota Motor Manufacturing Indonesia adalah melakukan penjualan dengan transfer pricing di luar prinsip kewajaran dan kelaziman usaha kepada perusahaan afiliasinya yang berada di Singapura, karena pajak di Singapura memang lebih rendah dibandingkan Indonesia. Indonesia menerapkan pajak 25 persen, sementara Singapura hanya 17 persen.

Sengketa dengan TMMIN ini terjadi karena koreksi yang dilakukan oleh Ditjen Pajak terhadap nilai penjualan dan pembayaran royalti TMMIN. Sengketa ini seputar laporan pajak tahun 2008. Dalam laporan pajaknya, TMMIN menyatakan nilai penjualan mencapai Rp32,9 triliun, namun Ditjen Pajak mengoreksi nilainya menjadi Rp34,5 triliun atau ada koreksi sebesar Rp1,5 triliun. 
Dengan nilai koreksi sebesar Rp1,5 triliun, TMMIN harus menambah pembayaran pajak sebesar Rp500 miliar (nasional.kontan.co.id dan kompasiana.com).

Fenomena penghindaran pajak juga terjadi pada tahun 2016. Peristiwa tersebut merupakan kebocoran data terbesar di dunia yang berasal dari firma hukum Mossack Fonseca yang berbasis di Panama atau disebut "Panama Papers". Data tersebut mengungkapkan keberadaan perusahaan di kawasan surga pajak (offshore companies) yang dikelola oleh firma hukum Mossack Fonseca yang disebut-sebut punya expertise dalam membuat perusahaan cangkang (shell companies) dan acapkali disalahgunakan untuk menyembunyikan aset. Data firma yang bocor itu juga mengungkap bahwa perbankan, firma hukum, dan pengusaha adalah tiga aktor yang banyak berperan dalam skandal penggelapan pajak (hukumonline.com).

Terdapat beberapa faktor yang mempengaruhi sebuah perusahaan dalam membayar pajaknya. Salah satunya adalah karakteristik sebuah perusahaan. Karakteristik perusahaan ialah ciri khas atau sifat yang melekat pada suatu entitas usaha (Surbakti, 2012). Karakteristik perusahaan dapat dilihat dari berbagai segi, salah satunya yaitu profitabilitas perusahaan. Ardyansah dan Zulaikha (2014) menyatakan bahwa profitabilitas adalah kemampuan perusahaan menghasilkan keuntungan dari aktivitas bisnisnya. Profitabilitas adalah alat ukur kinerja manajemen dalam mengelola kekayaan perusahaan yang dilihat dari laba perusahaan. Semakin tinggi profitabilitas perusahaan akan semakin tinggi pula laba bersih perusahaan yang dihasilkan. Laba perusahaan merupakan dasar dalam pengenaan pajak perusahaan. Ketika laba yang diperoleh membesar, maka jumlah 
Ida Ayu Intan Dwiyanti dan I ketut Jati. Pengaruh ...

pajak penghasilan akan meningkat sesuai dengan peningkatan laba perusahaan. Perusahaan yang memperoleh laba diasumsikan tidak melakukan penghindaran pajak karena mampu mengatur pendapatan dan pembayaran pajaknya (Maharani dan Suardana, 2014).

Penelitian Maharani dan Suardana (2014) menunjukkan hasil bahwa profitabilitas berpengaruh negatif terhadap penghindaran pajak. Begitu pula dengan penelitian yang dilakukan oleh Kurniasih dan Sari (2013) dimana mereka menyatakan bahwa profitabilitas berpengaruh negatif pada tax avoidance. Namun, hal tersebut bertentangan dengan penelitian yang dilakukan oleh Nugroho (2011) dan Fatharani (2012) yang menunjukkan bahwa ROA berpengaruh positif pada penghindaran pajak. Penelitian terkait yang sejalan dengan penelitian tersebut dilakukan oleh Darmawan dan Sukartha (2014) yang juga menunjukkan bahwa ROA berpengaruh positif terhadap tax avoidance.

Karakteristik perusahaan lainnya yang memengaruhi tingkat efektif pajak secara langsung yaitu capital intensity ratio atau rasio intensitas modal. Rasio intensitas modal atau intensitas aset tetap adalah seberapa besar perusahaan menginvestasikan asetnya pada aset tetap (Muzakki dan Darsono, 2015). Rodriguez dan Arias (2012) menyatakan bahwa aset tetap yang dimiliki perusahaan memungkinkan perusahaan memotong pajak akibat dari penyusutan aset tetap perusahaan setiap tahunnya. Hampir seluruh aset tetap akan mengalami penyusutan yang akan menjadi biaya penyusutan dalam laporan keuangan perusahaan. Sementara biaya penyusutan ini adalah biaya yang dapat dikurangkan dari penghasilan dalam perhitungan pajak perusahaan. Artinya semakin besar 
biaya penyusutan akan semakin kecil tingkat pajak yang harus dibayarkan perusahaan. Hal tersebut berdampak pada perusahaan dengan tingkat rasio intensitas modal yang besar menunjukan tingkat pajak efektif yang rendah.

Penelitian yang menghubungkan antara intensitas modal dengan penghindaran pajak adalah penelitian yang dilakukan oleh Rodriguez dan Arias (2012) yang menyatakan bahwa aset tetap perusahaan memungkinkan perusahaan untuk mengurangi beban pajaknya akibat dari penyusutan yang muncul dari aset tetap tersebut setiap tahunnya. Penelitian terdahulu yang dilakukan oleh Noor et al. (2010) menemukan bahwa capital intensity memiliki pengaruh positif terhadap penghindaran pajak, yang artinya semakin tinggi capital intensity perusahaan maka semakin tinggi penghindaran pajak perusahaan. Penelitian lain yang mendukung penelitian tersebut adalah penelitian yang dilakukan oleh Jessica dan Toly (2014) yang juga menunjukkan bahwa capital intensity berpengaruh positif terhadap penghindaran pajak. Namun, dalam penelitian Kuriah dan Asyik (2016) menunjukkan bahwa variabel capital intensity tidak memiliki pengaruh terhadap agresivitas pajak. Sama halnya dengan penelitian yang dilakukan oleh Putra dan Merkusiwati (2016) yang menghubungkan capital intensity ratio dengan tax avoidance mendapatkan hasil capital intensity ratio tidak berpengaruh terhadap tax avoidance.

Selain profitabilitas dan capital intensity, faktor lain yang dapat memengaruhi penghindaran pajak adalah inventory intensity atau intensitas persediaan. Semakin banyak persediaan perusahaan, maka semakin besar beban pemeliharaan dan penyimpanan dari persediaan tersebut. Beban pemeliharaan dan 
Ida Ayu Intan Dwiyanti dan I ketut Jati. Pengaruh ...

penyimpanan persediaan tersebut nantinya akan mengurangi laba dari perusahaan sehingga pajak yang dibayarkan akan berkurang (Andhari dan Sukartha, 2017). Manajer akan berusaha meminimalisir beban tambahan karena banyaknya persediaan agar tidak mengurangi laba perusahaan. Tetapi di sisi lain, manajer akan memaksimalkan biaya tambahan yang ditanggung untuk menekan beban pajak yang dibayar perusahaan (Putri dan Lautania, 2016).

Penelitian mengenai inventory intensity dilakukan oleh Adisamartha dan Noviari (2015) menghasilkan bahwa inventory intensity berpengaruh positif terhadap agresivitas pajak. Sedangkan penelitian yang dilakukan oleh Maesarah dkk. (2013) menunjukkan bahwa inventory intensity tidak berpengaruh terhadap penghindaran pajak. Penelitian lain yang mendukung penelitian Maesarah dkk. (2013) yaitu penelitian oleh Siregar dan Widyawati (2016) yang menyatakan bahwa inventory intensity tidak berpengaruh terhadap agresivitas pajak.

Pada hasil penelitian-penelitian sebelumnya, masih terdapat ketidakkonsistenan yang membuat peneliti tertarik untuk mengangkat kembali topik mengenai penghindaran pajak dengan variabel-variabel yang mendukungnya. Penelitian ini merupakan replikasi dari penelitian sebelumnya oleh Wiguna dan Jati (2017) tentang "Pengaruh Corporate Social Responsibility, Preferensi Risiko Eksekutif, dan Capital Intensity pada Penghindaran Pajak". Namun, penelitian ini menambahkan variabel profitabilitas dan inventory intensity dan mengurangi variabel corporate social responsibility dan preferensi risiko eksekutif. Perbedaan antara penelitian ini dengan penelitian sebelumnya yaitu terletak pada tahun pengamatan dan variabel bebasnya. Alasan menggunakan 
variabel profitabilitas adalah karena profitabilitas merupakan salah satu dasar penilaian kondisi suatu perusahaan. Semakin tinggi profitabilitas perusahaan akan semakin tinggi pula laba bersih perusahaan yang dihasilkan. Ketika terjadi peningkatan laba mengakibatkan jumlah pajak yang harus dibayar perusahaan juga semakin tinggi (Utami, 2013). Sedangkan alasan menggunakan variabel inventory intensity yaitu karena inventory intensity merupakan karakteristik perusahaan yang dapat memengaruhi tingkat efektif pajak. Apabila intensitas persediaan perusahaan tinggi maka akan meningkatkan tingkat agresivitas pajak perusahaan (Adisamartha dan Noviari, 2015).

Sampel dalam penelitian ini adalah perusahaan manufaktur yang terdaftar di Bursa Efek Indonesia periode 2015-2017. Perusahaan manufaktur adalah jenis perusahaan yang melakukan aktivitas usaha secara menyeluruh mulai dari pembelian bahan baku, pengolahan bahan baku menjadi barang jadi maupun barang setengah jadi hingga proses menjual kembali, sehingga dalam segala aktivitas usahanya sebagian besar terkait dengan aspek perpajakan (Mulyani dkk., 2013). Pemilihan perusahaan manufaktur sebagai sampel adalah karena perusahaan manufaktur merupakan salah satu sektor penyumbang penerimaan pajak negara terbesar selain perusahaan perbankan, perkebunan, kesehatan, dan pertambangan (Arianandini dan Ramantha, 2018). Selain itu, perusahaan manufaktur memiliki variasi data yang besar karena jumlah perusahaan manufaktur paling banyak dibandingkan dengan industri lain di Bursa Efek Indonesia. Alasan lain dipilihnya perusahaan manufaktur sebagai sampel penelitian adalah karena perusahaan manufaktur beberapa kali masuk sebagai 
Ida Ayu Intan Dwiyanti dan I ketut Jati. Pengaruh ...

wajib pajak yang difokuskan dalam daftar pemeriksaan Direktorat Jenderal Pajak, karena berdasarkan survei pada tahun 2012 terdapat 4000 perusahaan penanaman modal asing yang melaporkan pajaknya namun tidak memiliki besaran pajak yang terhutang karena mengalami kerugian selama tujuh tahun berturut-turut yang diindikasi melakukan praktek agresivitas pajak dan perusahaan tersebut bergerak di bidang manufaktur (Diantari dan Ulupui, 2016).

Profitabilitas menggambarkan kemampuan perusahaan dalam mendapatkan laba. Profitabilitas dapat diukur dengan berbagai macam rasio pengukuran, salah satunya yaitu return on assets (ROA). Semakin tinggi nilai ROA, maka semakin besar juga laba yang diperoleh perusahaan. Dalam hal ini, teori perilaku terencana (theory of planned behavior) dapat digunakan untuk menjelaskan perilaku wajib pajak dalam memenuhi kewajiban perpajakannya. Sebelum individu melakukan sesuatu, individu tersebut akan memiliki keyakinan mengenai hasil yang akan diperoleh dari perilakunya tersebut. Kemudian bersangkutan akan memutuskan bahwa akan melakukannya atau tidak melakukannya (Mustikasari, 2007). Jika perusahaan memperoleh laba, maka perusahaan tersebut cenderung patuh terhadap kewajibannya membayar pajak karena perusahaan memiliki keyakinan dan menganggap bahwa perusahaan mampu mengatur pendapatan serta membayar pajaknya.

Penelitian Maharani dan Suardana (2014) menunjukkan hasil bahwa profitabilitas berpengaruh negatif terhadap penghindaran pajak. Penelitian lain yang sejalan dengan penelitian Maharani dan Suardana (2014) yakni penelitian 
yang dilakukan oleh Kurniasih dan Sari (2013) dimana mereka menyatakan bahwa profitabilitas berpengaruh negatif pada tax avoidance.

Perusahaan dengan profitabilitas yang tinggi akan berdampak pada ETR perusahaan, dimana ETR dalam penelitian ini digunakan sebagai proksi untuk pengukuran penghindaran pajak. Ketika terjadi peningkatan laba, jumlah pajak yang harus dibayar perusahaan juga semakin meningkat, sehingga akan menyebabkan ETR perusahaan juga mengalami peningkatan. Apabila ETR perusahaan meningkat, maka hal tersebut menunjukkan bahwa tindakan penghindaran pajak yang dilakukan perusahaan mengalami penurunan. Jadi, semakin tinggi profitabilitas perusahaan akan semakin menekan tindakan tax avoidance karena perusahaan yang mempunyai profitabilitas tinggi cenderung akan melaporkan pajaknya dengan jujur dari pada perusahaan dengan profitabilitas yang rendah. Berdasarkan uraian tersebut, maka dapat dirumuskan hipotesis sebagai berikut.

$\mathrm{H}_{1}$ : Profitabilitas berpengaruh negatif pada penghindaran pajak.

Capital intensity berhubungan dengan investasi perusahaan dalam aset tetap. Semakin tinggi capital intensity suatu perusahaan, maka beban depresiasi aset tetap semakin meningkat. Hal tersebut akan menyebabkan laba perusahaan yang semakin menurun, sehingga pajak terutang perusahaan juga akan semakin menurun. Jika laba perusahaan menurun, maka perusahaan tersebut memiliki ETR yang rendah yang mengindikasikan tingkat penghindaran pajak yang makin tinggi. Hal tersebut karena perusahaan dengan aset tetap yang besar cenderung melakukan perencanaan pajak yang menyebabkan ETR-nya tergolong rendah. 
Ida Ayu Intan Dwiyanti dan I ketut Jati. Pengaruh ...

Sesuai dengan teori perilaku terencana, adanya niat untuk berperilaku dapat menimbulkan perilaku yang ditampilkan oleh individu. Dalam teori ini, norma subyektif menjelaskan pandangan seseorang terhadap kepercayaankepercayaan orang lain yang akan mempengaruhi niat individu, ditambah dengan adanya motivasi untuk mengikuti perilaku tersebut, maka individu tersebut akan merasakan tekanan sosial untuk melakukannya. Dengan adanya beban-beban yang disebabkan atas investasi perusahaan pada aset tetap, maka akan mendorong niat (intention) dalam penurunan laba yang akan membentuk sikap (attitude) untuk melakukan tindakan penghindaran pajak. Niat dalam berperilaku juga muncul karena keyakinan akan harapan normatif orang lain. Dalam hal ini, pihak manajemen memiliki keyakinan tentang harapan prinsipal untuk memperoleh laba tinggi dengan pengeluaran beban pajak serendah mungkin, sehingga manajemen perusahaan termotivasi untuk memenuhi harapan tersebut.

Penelitian yang dilakukan oleh Richardson dan Lanis (2007) memperoleh hasil capital intensity berpengaruh positif terhadap penghindaran pajak. Penelitian lain yang mendukung penelitian tersebut adalah penelitian yang dilakukan oleh Jessica dan Toly (2014) serta Putri dan Lautania (2016) yang juga menunjukkan bahwa capital intensity berpengaruh positif terhadap penghindaran pajak. Liu dan Cao (2007) dalam Ardyansah dan Zulaikha (2014) menyebutkan bahwa metode penyusutan aset didorong oleh hukum pajak, sehingga biaya penyusutan dapat dikurangkan pada laba sebelum pajak. Maka, semakin besar proporsi aktiva tetap dan biaya penyusutannya, perusahaan akan mempunyai nilai ETR yang rendah 
dan tindakan penghindaran pajaknya akan semakin tinggi. Berdasarkan uraian di atas, maka dapat dirumuskan hipotesis sebagai berikut.

$\mathrm{H}_{2}$ : Capital intensity berpengaruh positif pada penghindaran pajak.

Inventory intensity merupakan seberapa besar investasi perusahaan pada persediaan. Inventory intensity dapat diukur dari total ending inventory perusahaan, dimana perhitungan harga pokok persediaan dihitung dari jumlah persediaan awal ditambah dengan total pembelian persediaan selama satu periode dikurangi persediaan akhir. Semakin besar total persediaan, maka semakin tinggi harga pokok persediaan. Perhitungan harga pokok persediaan dapat menjadi pengurang laba, sehingga profitabilitas perusahaan juga akan menurun. Jika profitabilitas menurun, maka akan diikuti dengan penurunan jumlah pajak terhutang perusahaan sehingga ETR yang ditanggung perusahaan juga mengalami penurunan. Penurunan ETR tersebut menunjukkan bahwa tindakan penghindaran pajak yang meningkat.

Perusahaan dengan tingkat persediaan yang tinggi akan mengalami penurunan laba dikarenakan biaya tambahan dari persediaan tersebut bertindak sebagai pengurang laba perusahaan. Hal tersebut akan mendorong sikap (attitude) dan niat (intention) dalam berperilaku sesuai dengan teori perilaku terencana. Dalam hal ini, perilaku manajemen muncul dari keyakinan tentang harapan normatif orang lain yaitu prinsipal yang memiliki harapan untuk mendapatkan laba yang tinggi dan beban pajak yang rendah, sehingga manajemen perusahaan memiliki dorongan untuk mewujudkan harapan tersebut (normative beliefs). 
Ida Ayu Intan Dwiyanti dan I ketut Jati. Pengaruh ...

Penelitian yang dilakukan oleh Adisamartha dan Noviari (2015) menunjukkan bahwa inventory intensity berpengaruh positif terhadap agresivitas pajak. Tingginya tingkat intensitas persediaan perusahaan akan menyebabkan penurunan laba perusahaan karena biaya-biaya tambahan yang terkandung didalam persediaan. Perusahaan akan membayar pajak lebih rendah ketika perusahaan mengalami penurunan laba. ETR perusahaan juga akan menurun bila terjadi penurunan laba perusahaan. Dengan menurunnya ETR perusahaan, maka hal tersebut mengindikasikan meningkatnya tindakan penghindaran pajak. Oleh karena itu, dapat disimpulkan bahwa semakin tinggi inventory intensity perusahaan, maka tindakan penghindaran pajak yang dilakukan perusahaan akan semakin meningkat. Berdasarkan uraian di atas, maka dapat dirumuskan hipotesis sebagai berikut.

$\mathrm{H}_{3}$ : Inventory intensity berpengaruh positif pada penghindaran pajak.

\section{METODE PENELITIAN}

Penelitian ini dilakukan pada perusahaan manufaktur yang terdaftar di Bursa Efek Indonesia yang laporan keuangannya dilaporkan secara berkala. Penelitian ini dilakukan dengan mengambil data yang dapat diunduh melalui website resmi Bursa Efek Indonesia yaitu www.idx.co.id pada periode 2015-2017.

Objek dalam penelitian penelitian ini adalah profitabilitas, capital intensity, dan inventory intensity pada penghindaran pajak di perusahaan manufaktur yang terdaftar di Bursa Efek Indonesia periode 2015-2017. Data 
dalam penelitian ini diperoleh dari laporan keuangan perusahaan yang dapat diunduh melalui situs resmi Bursa Efek Indonesia, yaitu www.idx.co.id.

Populasi dalam penelitian ini adalah seluruh perusahaan manufaktur yang terdaftar di Bursa Efek Indonesia selama periode 2015-2017 yaitu sebanyak 150 perusahaan. Data populasi tersebut merupakan data per tahun 2017 yang diperoleh dari www.sahamok.com. Teknik yang digunakan adalah purposive sampling, yaitu teknik pengambilan sampel sumber data dengan menggunakan kriteria berdasarkan pertimbangan tertentu.

Analisis regresi linear berganda digunakan untuk menganalisis besarnya hubungan dan pengaruh variabel independen yang jumlahnya lebih dari dua terhadap variabel dependen. Analisis ini bertujuan untuk menguji pengaruh antara variabel bebas/ independen yaitu profitabilitas, capital intensity, dan inventory intensity secara parsial maupun simultan terhadap variabel terikat/ dependen yakni penghindaran pajak. Adapun persamaan regresinya yaitu sebagai berikut.

$\mathrm{Y}=\alpha+\beta_{1} \mathrm{X}_{1}+\beta_{2} \mathrm{X}_{2}+\beta_{3} \mathrm{X}_{3}+\mathrm{e}$

Keterangan:

$$
\begin{aligned}
& \mathrm{Y}=\text { Penghindaran Pajak } \\
& \mathrm{X}_{1} \quad=\text { Profitabilitas } \\
& \mathrm{X}_{2} \quad=\text { Capital Intensity } \\
& \mathrm{X}_{3} \quad=\text { Inventory Intensity } \\
& \alpha \quad=\text { Konstanta } \\
& \beta_{1,}, \beta_{2,} \beta_{3} \quad=\text { Koefisien Regresi }(\mathrm{x}) \\
& \text { e } \quad=\text { Error }
\end{aligned}
$$

\section{HASIL DAN PEMBAHASAN}

Pengujian dengan analisis statistik deskriptif bertujuan untuk mengetahui secara ringkas gambaran data mengenai ukuran pemusatan data, ukuran penyebaran data, 
Ida Ayu Intan Dwiyanti dan I ketut Jati. Pengaruh ...

serta kecenderungan suatu gugus data. Analisis ini juga berguna untuk menjelaskan karateristik sampel terutama mencakup nilai rata-rata (mean), nilai ektrim yaitu nilai minimum dan nilai maksimum, serta standar deviasi dari masing-masing variabel. Hasil dari statistik deskriptif tersebut dapat dilihat pada Tabel 2 berikut.

Tabel 2.

Hasil Analisis Statistik Deskriptif

\begin{tabular}{lccccc}
\hline & $\mathrm{N}$ & Minimum & Maximum & Mean & Std. Deviation \\
\hline Profitabilitas & 189 & 0,000 & 0,527 & 0,08481 & 0,082059 \\
Capital Intensity & 189 & 0,036 & 0,797 & 0,36610 & 0,167939 \\
Inventory Intensity & 189 & 0,011 & 0,596 & 0,19360 & 0,115618 \\
Penghindaran Pajak & 189 & 0,012 & 5,548 & 0,30622 & 0,406320 \\
Valid N (listwise) & 189 & & & & \\
\hline
\end{tabular}

Sumber: Data diolah, 2018

Profitabilitas pada penelitian ini diukur dengan proksi ROA. Berdasarkan hasil statistik deskriptif diperoleh nilai minimum profitabilitas sebesar 0,000 dan nilai maksimumnya yaitu sebesar 0,527 . Hal ini menunjukkan bahwa nilai terendah dari variabel profitabilitas terdapat pada perusahaan manufaktur yang terdaftar di BEI periode 2015-2017 yaitu sebesar 0,000 yang dimiliki oleh PT Star Petrochem Tbk (STAR) pada tahun 2015, sedangkan nilai tertingginya yaitu sebesar 0,527 dimiliki oleh PT Multi Bintang Indonesia Tbk (MLBI) pada tahun 2017. Rata-rata untuk variabel profitabilitas adalah 0,08481 , sedangkan deviasi standarnya yaitu sebesar 0,082059. Nilai deviasi standar lebih rendah dibandingkan dengan nilai rata-ratanya yang berarti bahwa sebaran data variabel profitabilitas sudah merata dan cenderung homogen karena nilai deviasi standarnya mendekati nol.

Nilai minimum variabel capital intensity adalah sebesar 0,036 sedangkan nilai maksimum sebesar 0,797. Hal ini menunjukkan bahwa nilai terendah dari 
variabel capital intensity pada perusahaan manufaktur yang terdaftar di BEI periode 2015-2017 yaitu sebesar 0,036 yang dimiliki oleh PT Duta Pertiwi Nusantara Tbk (DPNS) pada tahun 2017, sedangkan nilai tertingginya yaitu sebesar 0,797 dimiliki oleh PT PT Semen Baturaja (Persero) Tbk (SMBR) pada tahun 2016. Variabel capital intensity memiliki rata-rata sebesar 0,36610 yang menunjukkan bahwa rata-rata jumlah aset tetap yang dimiliki perusahaan sebesar 36,610 persen dari total aset perusahaan yang dijadikan sampel penelitian. Nilai deviasi standarnya adalah 0,167939, dimana nilai ini lebih rendah jika dibandingkan dengan nilai rata-ratanya. Hal ini berarti sebaran data capital intensity sudah merata dan cenderung homogen karena nilai deviasi standarnya mendekati nol.

Nilai minimum dari variabel inventory intensity adalah sebesar 0,011 dan untuk nilai maksimum yaitu sebesar 0,596. Hal ini menunjukkan bahwa nilai terendah dari variabel inventory intensity pada perusahaan manufaktur yang terdaftar di BEI periode 2015-2017 yaitu sebesar 0,011 yang dimiliki oleh PT Nippon Indosari Corporindo Tbk (ROTI) pada tahun 2017, sedangkan untuk nilai tertingginya yaitu sebesar 0,596 dimiliki oleh PT Gudang Garam Tbk (GGRM) tahun 2016. Diperoleh rata-rata sebesar 0,19360 yang menunjukkan bahwa ratarata jumlah persediaan yang dimiliki perusahaan sebesar 19,360 persen dari total aset perusahaan yang dijadikan sampel penelitian. Deviasi standar untuk inventory intensity adalah sebesar 0,115618. Hal ini berarti bahwa sebaran data inventory intensity sudah merata dan cenderung homogen karena nilai deviasi standarnya mendekati nol. 
Ida Ayu Intan Dwiyanti dan I ketut Jati. Pengaruh ...

Penghindaran pajak dalam penelitian ini diproksikan dengan ETR, yaitu perbandingan antara beban pajak dengan laba sebelum pajak. Berdasarkan analisis statistik deskriptif diperoleh nilai minimum penghindaran pajak adalah 0,012 dan nilai maksimumnya sebesar 5,548. Hal ini menunjukkan bahwa nilai terendah dari variabel penghindaran pajak pada perusahaan manufaktur yang terdaftar di BEI periode 2015-2017 yaitu sebesar 0,012 yang dimiliki oleh PT Kabelindo Murni Tbk (KBLM) pada tahun 2017, sedangkan nilai tertingginya yaitu sebesar 5,548 dimiliki oleh PT Indo Acitama Tbk (SRSN) pada tahun 2016. Variabel penghindaran pajak memiliki rata-rata sebesar 0,30622 yang berarti bahwa ratarata perusahaan yang dijadikan sampel dalam penelitian ini memiliki beban pajak sebesar 30,622 persen dari laba sebelum pajak perusahaan. Rata-rata pembayaran pajak yang cukup tinggi ini menunjukkan bahwa tindakan penghindaran pajak yang dilakukan perusahaan masih tergolong rendah. Deviasi standar untuk penghindaran pajak adalah sebesar 0,406320. Hal ini berarti terjadi penyimpangan antara nilai penghindaran pajak dengan nilai rata-ratanya yaitu sebesar 0,406320.

Analisis regresi linear berganda merupakan analisis yang digunakan untuk mengetahui pengaruh dua atau lebih variabel independen $(\mathrm{X})$ pada suatu variabel dependen (Y). Perhitungan koefisien regresi dilakukan dengan analisis regresi melalui software SPSS 18.0 for Windows, diperoleh hasil yang ditunjukan pada Tabel 3. 
Tabel 3.

Hasil Analisis Regresi Linear Berganda

\begin{tabular}{|c|c|c|c|c|c|c|}
\hline \multirow[t]{2}{*}{ Model } & & \multicolumn{2}{|c|}{$\begin{array}{c}\text { Unstandardized } \\
\text { Coefficients }\end{array}$} & \multirow{2}{*}{$\begin{array}{l}\text { Standardized } \\
\text { Coefficients } \\
\text { Beta }\end{array}$} & \multirow[b]{2}{*}{$\mathrm{t}$} & \multirow{2}{*}{ Sig. } \\
\hline & & B & Std. Error & & & \\
\hline 1 & (Constant) & $-0,055$ & 0,056 & & $-0,968$ & 0,334 \\
\hline & Profitabilitas & $-0,115$ & 0,053 & $-0,127$ & $-2,153$ & 0,033 \\
\hline & Capital Intensity & 0,380 & 0,053 & 0,423 & 7,146 & 0,000 \\
\hline & Inventory Intensity & 0,354 & 0,058 & 0,367 & 6,155 & 0,000 \\
\hline
\end{tabular}

R Square

Adjusted R Square

0,374

F Statistik

0,364

Signifikansi

36,840

Sumber: Data diolah, 2018

Berdasarkan hasil analisis regresi linier berganda seperti yang disajikan pada Tabel 3, maka dapat dibuat persamaan regresi sebagai berikut.

$$
\begin{gathered}
Y=\alpha+\beta_{1} X_{1}+\beta_{2} X_{2}+\beta_{3} X_{3}+e \\
Y=-0,055-0,115 X_{1}+0,380 X_{2}+0,354 X_{3}+e
\end{gathered}
$$

Hasil uji pada tabel 3 menunjukkan bahwa diperolehnya adjusted $\mathrm{R}^{2}$ (koefisien determinasi yang telah disesuaikan) adalah sebesar 0,364. Ini berarti variasi penghindaran pajak (Y) dapat dipengaruhi secara signifikan oleh variabel profitabilitas $\left(\mathrm{X}_{1}\right)$, capital intensity $\left(\mathrm{X}_{2}\right)$ dan inventory intensity $\left(\mathrm{X}_{3}\right)$ sebesar 36,4 persen, sedangkan sisanya sebesar 63,6 persen dijelaskan oleh faktor-faktor lain yang tidak dijelaskan dalam model penelitian.

Hasil uji $\mathrm{F}$ ( $F$ test) pada Tabel 3 menunjukkan bahwa nilai $\mathrm{F}$ hitung sebesar 36,840 dengan nilai signifikansi P value 0,000 yang lebih kecil dari $\alpha=$ 0,05 , ini berarti model yang digunakan pada penelitian ini adalah layak. Hasil ini menunjukkan bahwa ketiga variabel independen yaitu profitabilitas, capital intensity, dan inventory intensity tepat memprediksi atau menjelaskan fenomena penghindaran pajak, atau dapat diartikan bahwa profitabilitas, capital intensity, dan inventory intensity secara simultan berpengaruh signifikan terhadap 
Ida Ayu Intan Dwiyanti dan I ketut Jati. Pengaruh ...

penghindaran pajak. Hal ini berarti model dapat digunakan untuk analisis lebih lanjut atau dengan kata lain model dapat digunakan untuk memproyeksikan karena hasil goodness of fitnya baik dengan nilai $\mathrm{F}$ hitung sebesar 36,840 dengan nilai signifikansi $\mathrm{P}$ value 0,000 .

Hipotesis pertama pada penelitian ini menyatakan bahwa profitabilitas berpengaruh negatif pada penghindaran pajak. Berdasarkan hasil pengujian dengan analisis regresi liniar berganda, diperoleh nilai signifikansi sebesar 0,033 dengan nilai koefisien regresi sebesar $-0,115$. Nilai signifikansi $0,033<0,050$ menandakan bahwa profitabilitas berpengaruh pada ETR sebagai proksi penghindaran pajak. Nilai koefisien regresi sebesar $-0,115$ menunjukkan hubungan negatif antara profitabilitas dengan ETR. Hal tersebut berarti bahwa semakin tinggi profitabilitas, semakin rendah ETR perusahaan. Nilai ETR perusahaan yang rendah tersebut mengindikasikan tingginya tindakan penghindaran pajak. Maka, semakin tinggi profitabilitas perusahaan, semakin tinggi tindakan penghindaran pajak yang dilakukan perusahaan. Hasil pengujian ini tidak dapat mendukung hipotesis pertama. Dengan demikian, hipotesis pertama ditolak.

Hasil penelitian ini tidak mendukung penelitian yang dilakukan oleh Maharani dan Suardana (2014) serta Kurniasih dan Sari (2013), namun mendukung hasil penelitian oleh Nugroho (2011), Surbakti (2012), dan Fatharani (2012). Berdasarkan data dari sampel, peningkatan ROA tidak diikuti dengan peningkatan ETR, sehingga profitabilitas memiliki pengaruh positif pada tindakan penghindaran pajak. Selain itu, hasil penelitian ini juga tidak dapat mendukung 
teori perilaku terencana (theory of planned behavior) dimana teori tersebut menyatakan bahwa jika perusahaan memiliki profitabilitas yang tinggi maka perusahaan tersebut cenderung patuh terhadap kewajibannya membayar pajak dan perusahaan dianggap mampu dalam mengatur pendapatannya, sehingga terjadi penurunan tindakan penghindaran pajak.

Berdasarkan hasil pengujian dengan menggunakan regresi liniar berganda, diperoleh nilai signifikansi sebesar 0,000 dengan nilai koefisien regresi sebesar 0,380. Nilai signifikansi $0,000<0,050$ menunjukkan bahwa capital intensity berpengaruh pada penghindaran pajak. Nilai koefisien regresi sebesar 0,380 mempunyai arti terdapat hubungan positif antara capital intensity dan penghindaran pajak. Investasi perusahaan pada aset tetap menyebabkan adanya beban depresiasi. Beban depresiasi akan mempengaruhi pajak perusahaan, hal ini dikarenakan beban depresiasi akan bertindak sebagai pengurang laba yang menyebabkan rendahnya pajak terhutang perusahaan. Maka, semakin tinggi capital intensity perusahaan akan menyebabkan semakin rendahnya nilai ETR perusahaan tersebut dan meningkatnya tindakan penghindaran pajak perusahaan. Pada penelitian ini, hipotesis kedua menyatakan bahwa capital intensity berpengaruh positif pada penghindaran pajak, yang berarti bahwa hipotesis tersebut dapat diterima.

Hasil penelitian ini sejalan dengan penelitian yang dilakukan oleh Richardson dan Lanis (2007), Noor et al. (2010), Jessica dan Toly (2014), serta Putri dan Lautania (2016) yang menunjukkan bahwa capital intensity berpengaruh positif terhadap penghindaran pajak. Hasil penelitian ini juga mendukung teori 
Ida Ayu Intan Dwiyanti dan I ketut Jati. Pengaruh ...

perilaku terencana. Dengan adanya beban-beban yang disebabkan atas investasi perusahaan pada aset tetap, maka akan mendorong niat (intention) dalam penurunan laba yang akan membentuk sikap (attitude) untuk melakukan tindakan penghindaran pajak. Niat dalam berperilaku juga muncul karena keyakinan akan harapan normatif orang lain. Dalam hal ini, pihak manajemen memiliki keyakinan tentang harapan prinsipal untuk memperoleh laba tinggi dengan pengeluaran beban pajak serendah mungkin, sehingga manajemen perusahaan termotivasi untuk memenuhi harapan tersebut.

Hipotesis ketiga pada penelitian ini menyatakan bahwa inventory intensity berpengaruh positif pada penghindaran pajak. Berdasarkan hasil pengujian dengan menggunakan regresi liniar berganda, diperoleh nilai signifikansi sebesar 0,000 dengan nilai koefisien regresi sebesar 0,354 . Nilai signifikansi $0,000<0,050$ mengindikasikan bahwa inventory intensity berpengaruh pada penghindaran pajak. Nilai koefisien regresi sebesar 0,354 menunjukkan bahwa terdapat hubungan positif antara inventory intensity dengan penghindaran pajak. Jika inventory intensity perusahaan tinggi, nilai ETR akan mengalami penurunan yang disebabkan oleh biaya tambahan dari persediaan yang bertindak sebagai pengurang laba. Hal tersebut mengindikasikan tingkat penghindaran pajak yang semakin tinggi. Oleh karena itu, dapat disimpulkan bahwa semakin tinggi inventory intensity suatu perusahaan, maka semakin tinggi penghindaran pajak perusahaan tersebut. Hasil pengujian ini dapat mendukung hipotesis ketiga yang menyatakan bahwa inventory intensity berpengaruh positif pada penghindaran pajak. 
Hasil penelitian ini mendukung penelitian yang dilakukan oleh Adisamartha dan Noviari (2015) menunjukkan bahwa inventory intensity berpengaruh positif terhadap agresivitas pajak. Inventory intensity menunjukkan keefektifan dan keefisienan perusahaan untuk mengatur investasinya dalam persediaan. Tingginya tingkat persediaan dalam perusahaan akan menimbulkan tambahan beban bagi perusahaan. Biaya tambahan yang timbul dari adanya persediaan tersebut dapat mempengaruhi tindakan penghindaran pajak. Hasil penelitian ini juga dapat mendukung teori perilaku terencana yang menjelaskan bahwa biaya tambahan atas persediaan akan mendorong sikap (attitude) dan niat (intention) dalam berperilaku dengan melakukan tindakan penghindaran pajak. Perilaku manajemen muncul dari keyakinan tentang harapan normatif orang lain yaitu prinsipal yang memiliki harapan untuk mendapatkan laba yang tinggi dan membayar beban pajak yang rendah, sehingga manajemen perusahaan memiliki dorongan untuk mewujudkan harapan tersebut.

Berdasarkan hasil penelitian yang menunjukkan bahwa capital intensity dan inventory intensity berpengaruh positif pada penghindaran pajak. Penelitian ini membuktikan bahwa tidak semua variabel secara teori dapat mempengaruhi penghindaran pajak. Hasil penelitian ini dapat memberikan implikasi bagi pihak manajemen perusahaan, pemerintah serta pihak-pihak yang berkepentingan. Tindakan penghindaran pajak dilakukan manajemen perusahan untuk meminimalkan beban pajak perusahaan. Namun, dalam hal ini sebaiknya pihak manajemen perusahaan harus selalu memperhatikan kebijakan-kebijakan yang akan diambil dan mempertimbangkan risiko-risiko yang akan diterima dari setiap 
Ida Ayu Intan Dwiyanti dan I ketut Jati. Pengaruh ...

pengambilan keputusan, sehingga nantinya tidak menimbulkan kerugian baik bagi individu maupun kelompok. Selain itu, pemerintah dalam peranannya melalui Direktorat Jenderal Pajak agar lebih memantau kegiatan-kegiatan perusahaan dalam mengambil kebijakan atau prosedur agar tetap berada dalam koridor yang tepat dan tidak melanggar hukum yang berlaku.

\section{SIMPULAN}

Hasil penelitian ini tidak dapat mendukung hipotesis pertama yang menyatakan bahwa profitabilitas berpengaruh negatif pada penghindaran pajak.

Capital intensity berpengaruh positif pada penghindaran pajak, yang berarti bahwa hipotesis kedua diterima. Semakin tinggi capital intensity suatu perusahaan, semakin tinggi tingkat penghindaran pajak yang dilakukan perusahaan tersebut. Investasi perusahaan pada aset tetap menyebabkan adanya beban depresiasi. Biaya tersebut akan bertindak sebagai pengurang pajak. Ketika capital intensity meningkat, nilai ETR perusahaan akan menurun yang disebabkan oleh biaya tambahan tersebut. Maka, perusahaan akan semakin agresif terhadap kewajiban perpajakannya atau tindakan penghindaran pajak perusahaan akan meningkat.

Inventory intensity berpengaruh positif pada penghindaran pajak. Hasil penelitian ini mendukung hipotesis ketiga. Hal ini berarti bahwa semakin tinggi inventory intensity suatu perusahaan maka semakin tinggi tingkat penghindaran pajak perusahaan tersebut. Intensitas persediaan perusahaan yang tinggi akan meningkatkan biaya-biaya yang terkandung dalam persediaan. Biaya-biaya 
tambahan tersebut akan mengurangi laba perusahaan. Jika laba menurun, ETR juga akan mengalami penurunan yang dapat mengindikasikan tingkat penghindaran pajak perusahaan semakin tinggi. Maka dari itu, semakin tinggi inventory intensity suatu perusahaan, maka semakin tinggi penghindaran pajak perusahaan tersebut.

Bagi pihak manajemen perusahaan sebaiknya tetap memantau profitabilitas, capital intensity, dan inventory intensity sebagai upaya untuk meminimalkan tindakan penghindaran pajak yang dilakukan perusahaan. Selain itu, manajemen perusahaan sebaiknya juga berhati-hati dalam menentukan kebijakan, khususnya mengenai pajak agar tidak tergolong kedalam tindakan penghindaran pajak.

Sebaiknya sebelum melakukan investasi pada suatu perusahaan, para investor terlebih dulu memperhatikan keadaan perusahaan. Investor juga sebaiknya lebih meningkatkan pengawasan terhadap keputusan atau kebijakan yang diambil oleh perusahaan agar tidak terjadi tindakan oportunitis atau tindakan-tindakan lainnya yang tidak diinginkan yang dapat menyebabkan kerugian bagi perusahaan maupun pemegang saham.

Nilai adjusted $\mathrm{R}^{2}$ pada penelitian ini masih cukup rendah yaitu sebesar 0,364. Hal ini berarti variasi variabel penghindaran pajak dapat dijelaskan oleh variabel profitabilitas, capital intensity dan inventory intensity hanya sebesar 36,4 persen, sedangkan sisanya sebesar 63,6 persen dijelaskan oleh faktor-faktor lain yang tidak dimasukkan dalam model penelitian ini. Oleh karena itu, peneliti selanjutnya dapat menambahkan beberapa variabel bebas yang diduga mampu 
Ida Ayu Intan Dwiyanti dan I ketut Jati. Pengaruh ...

mempengaruhi praktik penghindaran pajak, seperti leverage, nilai perusahaan, kepemilikan institusional, dan corporate social responsibility. Peneliti selanjutnya juga dapat memperluas ruang lingkup penelitiannya, tidak hanya pada perusahaan di sektor manufaktur namun juga pada perusahaan di sektor-sektor lainnya.

\section{REFERENSI}

Adisamartha, I. B. P. F., \& Noviari, N. (2015). Pengaruh Likuiditas, Leverage, Intensitas Persediaan, dan Intensitas Aset Tetap Pada Tingkat Agresivitas Wajib Pajak Badan. E-Jurnal Akuntansi Universitas Udayana, 13(3), 9731000 .

Ampriyanti, N. M., \& Merkusiwati, N. K. L. A. (2016). Pengaruh Tax Avoidance Jangka Panjang Terhadap Nilai Perusahaan dengan Karakteristik Eksekutif Sebagai Variabel Pemoderasi. E-Jurnal Akuntansi Universitas Udayana, 16(3), 2231-2259.

Andhari, P. A. S., \& Sukartha, I. M. (2017). Pengaruh Pengungkapan Corporate Social Responsibility, Profitabilitas, Inventory Intensity, Capital Intensity, dan Leverage pada Agresivitas Pajak. E-Jurnal Akuntansi Universitas Udayana, 18(3), 2115-2142.

Anissa, P. S. (2015). Pengaruh Kepemilikan Institusional, Struktur Dewan Komisaris, Kualitas Audit dan Komite Audit terhadap Tax Avoidance. Jurnal Mahasiswa Ekonomi Akuntansi, 1(14).

Ardyansah, D., \& Zulaikha, Z. (2014). Pengaruh Size, Leverage, Profitability, Capital Intensity Ratio, dan Komisaris Independen Terhadap Effective Tax Rate (ETR). Diponegoro Journal of Accounting, 3(2), 371-379.

Arianandini, P. W., \& Ramantha, I. W. (2018). Pengaruh Profitabilitas, Leverage, dan Kepemilikan Institusional Pada Tax Avoidance. E-Jurnal Akuntansi Universitas Udayana, 22(3), 2088-2116. https://doi.org/10.24843/EJA.2018.v22.i03.p17

Darmawan, I. G. H., \& Sukartha, I. M. (2014). Pengaruh Penerapan Corporate Governance, Leverage, Return On Assets, dan Ukuran Perusahaan Pada Penghindaran Pajak. E-Jurnal Akuntansi Universitas Udayana, 9(1), 143161. 
Diantari, P. R., \& Ulupui, I. A. (2016). Pengaruh Komite Audit, Proporsi Komisaris Independen, dan Proporsi Kemepilikan Institusional Terhadap Tax Avoidance. E-Jurnal Akuntansi Universitas Udayana, 16(1), 702732.

Fatharani, N. (2012). Pengaruh Karakteristik Kepemilikan, Reformasi Perpajakan, dan Hubungan Politik Terhadap Tindakan Pajak Agresif. Skripsi. Universitas Indonesia. Depok.

Hanlon, M., \& Heitzman, S. (2010). A Review of Tax Research. Journal of Accounting and Economics, 50(2), 127-178. https://doi.org/10.1016/j.jacceco.2010.09.002

Himawan, A. (2017). Fitra: Setiap Tahun, Penghindaran Pajak Capai Rp110 Triliun. Retrieved from https://www.suara.com/bisnis/2017/11/30/190456/fitra-setiap-tahunpenghindaran-pajak-capai-rp110-triliun

Idris, U. (2013). Sengketa Pajak Toyota Motor Menanti Palu Hakim. Retrieved from https://nasional.kontan.co.id/news/sengketa-pajak-toyota-motormenanti-palu-hakim

Jessica, \& Toly, A. A. (2014). Pengaruh Pengungkapan Corporate Social Responsibility Terhadap Agresivitas Pajak. Tax \& Accounting Review, $4(1)$.

Kempis, K. (2017). Dugaan Transfer Pricing Toyota. Retrieved from https://www.kompasiana.com/kompaskampus/58b8c532b69373f804571ed a/dugaan-transfer-pricing-toyota

Kuriah, H. L., \& Asyik, N. F. (2016). Pengaruh Karakteristik Perusahaan dan Corporate Social Responsibility Terhadap Agresivitas Pajak. Jurnal Ilmu dan Riset Akuntansi, 5(3), 2460-0585.

Kurniasih, T., \& Sari, M. M. R. (2013). Pengaruh Return on Aset, Leverage, Corporate Governance, Ukuran Perusahaan, dan Kompensasi Rugi Fiskal pada Tax Avoidance. Buletin Studi Ekonomi, 18(1), 1-84.

Liu, X., \& Cao, S. (2007). Determinants of Corporate Effective Tax Rates: Evidence from Listed Companies in China. The Chinese Economy, 40(6), 49-67. https://doi.org/10.2753/CES1097-1475400603

Maesarah, Y., Atikah, S., \& Husnaini, W. (2013). Pengaruh Karakteristik Perusahaan dan Corporate Social Responsibility Terhadap Penghindaran Pajak. Proceeding Konferensi Regional Akuntansi II. Universitas Mataram. 
Maharani, I. G. A. C., \& Suardana, K. A. (2014). Pengaruh Corporate Governance, Profitabilitas, dan Karakteristik Eksekutif pada Tax Avoidance Perusahaan Manufaktur. E-Jurnal Akuntansi Universitas Udayana, 9(2), 525-539.

Mulyani, S., Darminto, \& N.P, M. . W. E. (2013). Pengaruh Karakteristik Perusahaan, Koneksi Politik, dan Reformasi Perpajakan terhadap Penghindaran Pajak (Studi pada Perusahaan Manufaktur yang terdaftar di Bursa Efek tahun 2008-2012). Jurnal Mahasiswa Perpajakan, 2(1).

Mustikasari, E. (2007). Kajian Empiris Tentang Kepatuhan Wajib Pajak Badan di Perusahaan Industri Pengolahan di Surabaya. Simposium Nasional Akuntansi X.

Muzakki, M. R., \& Darsono, D. (2015). Pengaruh Corporate Social Responsibility dan Capital Intensity Terhadap Penghindaran Pajak. Diponegoro Journal of Accounting, 4(3), 445-452.

NNP. (2013). Panama Papers Hingga Offshore Leaks, Skandal yang Melibatkan Law Firm. from https://hukumonline.com/lt5704efc5c2031/panama-papers-hinggaoffshore-leaks--skandal-yang-melibatkan-law-firm

Noor, R. M., Fadzillah, N. S. M., \& Nor Azam, M. (2010). Corporate Tax Planning: A Study On Corporate Effective Tax Rates of Malaysian Listed Companies. International Journal of Trade, Economics and Finance, 1(2), 189-193.

Nugroho, A. A. (2011). Pengaruh Hubungan Politik dan Reformasi Perpajakan Terhadap Tarif Pajak Efektif pada Perusahaan yang terdaftar di Bursa Efek Indonesia Tahun 2008-2009. Skripsi. Universitas Indonesia. Depok.

Putra, I. G. L. N. D. C., \& Merkusiwati, N. K. L. A. (2016). Pengaruh Komisaris Independen, Leverage, Size, dan Capital Intensity Ratio pada Tax Avoidance (Studi pada Perusahaan Manufaktur di Bursa Efek Indonesia Periode 2012-2014). E-Jurnal Akuntansi Universitas Udayana, 17(1), 690-714.

Putri, C. L., \& Lautania, M. F. (2016). Pengaruh Capital Intensity Ratio, Inventory Intensity Ratio, Ownership Strucutre, dan Profitability Terhadap Effective Tax Rate (ETR) (Studi pada Perusahaan Manufaktur yang Terdaftar di Bursa Efek Indonesia Tahun 2011-2014). Jurnal Ilmiah Mahasiswa Ekonomi Akuntansi, 1(1), 101-119.

Resmi, S. (2012). Perpajakan (5 ed.). Jakarta: Salemba Empat. 
Richardson, G., \& Lanis, R. (2007). Determinants of Variability in Corporate Effective Tax Rate and Tax Reform: Evidence from Australia. Journal of Accounting and Public Policy, 26(6), 689-704. https://doi.org/10.1016/J.JACCPUBPOL.2007.10.003

Rodriguez, E., \& Arias, A. (2012). Do Business Characteristics Determine an Effective Tax Rate? The Chinese Economy, 45(6), 60-83. https://doi.org/10.2753/CES1097-1475450604

Siregar, R., \& Widyawati, D. (2016). Pengaruh Karakteristik Perusahaan Terhadap Penghindaran Pajak pada Perusahaan Manufaktur di BEI. Jurnal Ilmu dan Riset Akuntansi, 5(2), 2460-0585.

Suandy, E. (2011). Hukum Pajak (5 ed.). Jakarta: Salemba Empat.

Surbakti, T. A. V. (2012). Pengaruh Karakteristik Perusahaan dan Reformasi Perpajakan Terhadap Penghindaran Pajak di Perusahaan Industri Manufaktur yang terdaftar di Bursa Efek Indonesia Tahun 2008-2010. Tesis. Universitas Indonesia. Depok.

Utami, N. W. (2013). Pengaruh Struktur Corporate Governance, Size, dan Profitabilitas Perusahaan Terhadap Tax Avoidance (Studi Pada Perusahaan Pertambangan dan Manufaktur yang terdaftar di Bursa Efek Indonesia Tahun 2009-2011). Skripsi. Universitas Sebelas Maret. Surakarta.

Wiguna, I. P. P., \& Jati, I. K. (2017). Pengaruh Corporate Social Responsibility, Preferensi Risiko Eksekutif, dan Capital Intensity pada Penghindaran Pajak. E-Jurnal Akuntansi Universitas Udayana, 21(1), 418-446.

Xynas, L. (2010). Tax Planning, Avoidance and Evasion in Australia 1970-2010: The Regulatory Responses and Taxpayer Compliance. Revenue Law Journal, 20(1).

Zain, M. (2007). Manajemen Perpajakan. Jakarta: Salemba Empat. 